\title{
Effect of Different Spacing and Nutrient Sources on Growth and Yield of Zaid Finger Millet (Eleusine coracana (L.) Gaertn)
}

\author{
B. S. Manojgowda*, Rajesh Singh and Wasim Khan
}

Department of Agronomy, Sam Higginbottom University of Agriculture, Technology and Sciences, Prayagraj, UttarPradesh, India

*Corresponding author

\section{Keywords}

Finger Millet, Spacing, RDN, Vermicompost, Yield

\section{Article Info}

Accepted:

20 January 2021

Available Online:

10 February 2021
A field experiment was conducted during Zaid season 2020 at Crop Research Farm (CRF), Department of Agronomy, SHUATS, Prayagraj (UP) on sandy loam soil to investigate the effect of different spacing and nutrient sources on growth and yield of Zaid finger millet. The treatments consisted of spacing viz., $20 \mathrm{~cm} \mathrm{x} 10 \mathrm{~cm}, 30 \mathrm{~cm} \times 10 \mathrm{~cm}$ and $40 \mathrm{~cm} \times 10$ $\mathrm{cm}$ and nutrient sources viz., 100\% RDN, 100\% $\mathrm{N}$ through vermicompost and $50 \% \mathrm{RDN}+$ $50 \% \mathrm{~N}$ through vermicompost whose effect is observed on finger millet (var. Godra-OT). The experiment was laid out in randomized block design with nine treatments replicated thrice. Study revealed that spacing $20 \mathrm{~cm} \mathrm{x} 10 \mathrm{~cm}+50 \% \mathrm{RDN}+50 \% \mathrm{~N}$ through vermicompost recorded significantly higher plant height $(93.95 \mathrm{~cm})$, number of tillers/running row meter (36.69) and plant dry weight (12.82 g) at harvest stage as compared to all the treatment combinations. The spacing $20 \mathrm{~cm} \times 10 \mathrm{~cm}+50 \% \mathrm{RDN}+$ $50 \% \mathrm{~N}$ through vermicompost also recorded significantly higher number of grains/ear head (1912.35), number of fingers/ear head $(6.41)$, fingers length $(9.04 \mathrm{~cm})$, grain yield $(2.74$ $\mathrm{t} / \mathrm{ha})$ and biological yield (7.41 t/ha) as compared to all the treatment combinations.

\section{Introduction}

Finger millet (Eleusine coracana) is an important nutri cereal crop grown in India and has the pride place in having highest productivity among millets. Finger millet is a relished food crop of the semi-arid tropics of Asia and Africa and has been an indispensable component of dry land farming systems. Today, the crop is ranked fourth globally in importance among millets after sorghum, pearl millet and foxtail millet. It is cultivated in more than 25 countries in the world. In India, finger millet is primarily grown in the states of Karnataka, Uttarakhand, Maharashtra and Tamil Nadu. Millet is a group of small grown around the world for food and fodder. Millets is known to be "crops of the future" as it well adapted and cultivated under harsh environment of arid and semi-arid region (Resmisa, 2012). The grain content $9.2 \%$ proteins, $1.29 \%$ fats, $76.32 \%$ carbohydrates, $2.2 \%$ mineral, $3.90 \%$ ash, $0.33 \%$ calcium. Vitamin A, B and phosphorus are also present in smaller quantity, iodine content in finger millet is 
reported to be the highest among food grain (Upadhyaya, 2001).

The modern agronomic approaches like suitable planting and fertilizer application were imperative in boosting the yields. Crop geometry is an important factor to achieve higher production by better utilization of moisture and nutrients from the soil (root spread) and above ground (plant canopy) by harvesting maximum possible solar radiation and in turn better photosynthates formation (Uphoff et al., 2011). In finger millet the optimum density of plant population per unit area under appropriate spacing to obtain maximum yield. It is also quite important to address plant density with respect to soil fertility and millet variety (Koriret al, 2018). The productivity of finger millet can be increased by applying judicious combination of organic and inorganic fertilizers which helps to improve the soil health as well as the productivity of finger millet (Ramamurthy et al., 1993). Soil nutrient application rates, schedule of nitrogen fertilizer application and spacing are among the major agronomic practice which requires due to attention (Bayala et al., 2002). Vermicompost are good superlatives for organic farming, vermicompost has significantly higher $\mathrm{K}$ contents than the cow dung compost. Vermicompost providing nutrient such as available $\mathrm{N}$, soluble $\mathrm{K}$, exchangeable $\mathrm{Ca}, \mathrm{Mg}$, $\mathrm{P}$ and micro elements such as Fe, Mo, $\mathrm{Zn}$ and $\mathrm{Cu}$, which can easily taken up by plants. Adding of vermicompost to soil improves the chemical and biological properties, improve the soil structure, increasing the water holding capacity and porosity. Application of $\mathrm{N}$ fertilizer with organic sources increases yield and soil health. Therefore, in view of the above, the present study was investigated with an aim to find out standard spacing and nutrient management of finger millet to achieve high crop yield under Zaid season of eastern Uttar Pradesh condition.

\section{Materials and Methods}

The experiment was carried out to study the "Effect of Different Spacing and Nutrient Sources on Growth and Yield of Zaid Finger Millet (Eleusine coracana (L.) Gaertn), during Zaid season 2020 at Crop Research Farm (CRF), Department of Agronomy, Naini Agricultural Institute, Sam Higginbottom University of Agriculture, Technology and Sciences, Prayagraj, Uttar Pradesh. The Crop Research Farm is situated at $25.75^{\circ} \mathrm{N}$ latitude, $87.19^{\circ}$ E longitude and at an altitude of $98 \mathrm{~m}$ above mean sea level.

The field trial was laid out in a randomized block design with consisted of nine treatments replicated thrice viz., $\mathrm{T}_{1}: 20 \mathrm{~cm} \times 10 \mathrm{~cm}+$ $100 \%$ RDN, $\mathrm{T}_{2}: 20 \mathrm{~cm} \times 10 \mathrm{~cm}+100 \% \mathrm{~N}$ through vermicompost, $\mathrm{T}_{3}: 20 \mathrm{~cm} \times 10 \mathrm{~cm}+$ $50 \% \mathrm{RDN}+50 \% \mathrm{~N}$ through vermicompost, $\mathrm{T}_{4}: 30 \mathrm{~cm} \mathrm{x} 10 \mathrm{~cm}+100 \% \mathrm{RDN}, \mathrm{T}_{5}: 30 \mathrm{~cm} \mathrm{x}$ $10 \mathrm{~cm}+100 \% \mathrm{~N}$ through vermicompost, $\mathrm{T}_{6}$ : $30 \mathrm{~cm} \times 10 \mathrm{~cm}+50 \% \mathrm{RDN}+50 \% \mathrm{~N}$ through vermicompost, $\mathrm{T}_{7}: 40 \mathrm{~cm} \times 10 \mathrm{~cm}+100 \%$ RDN, $\mathrm{T}_{8}: 40 \mathrm{~cm} \times 10 \mathrm{~cm}+100 \% \mathrm{~N}$ through vermicompost and $\mathrm{T}_{9}: 40 \mathrm{~cm} \times 10 \mathrm{~cm}+50 \%$ $\mathrm{RDN}+50 \% \mathrm{~N}$ through vermicompost. Finger millet variety "Godra-OT" (Farmer variety in Orissa) was used during Zaid season 2020. Vermicompost was applied on $\mathrm{N}$-equivalent basis. All nutrients were applied through soil as urea, single super phosphate (SSP) and muriate of potash (MOP). Full dose of $\mathrm{P}, \mathrm{K}$ and vermicompost was applied basal for respective plots, half dose of $\mathrm{N}$ (as urea) was applied basal and the remaining at active tillering stage.

The growth parameters were recorded at periodical intervals of 20,40,60, 80 DAS and at harvest stage from the randomly selected five plants in each treatment. Statistically analysis was done and mean compared at5\% probability level for significant results. 


\section{Results and Discussion}

The growth parameters like plant height, number of tillers and plant dry weight presented in Table 1 and yield attributes and yield in Table 2 were significantly affected by the different spacing and nutrient sources.

\section{Plant height (cm)}

Plant height during the period of growth has shown significant variation and tabulated in Table 1. The results of the present investigation revealed that spacing $20 \mathrm{~cm} \times 10$ $\mathrm{cm}+50 \% \mathrm{RDN}+50 \% \mathrm{~N}$ through vermicompost significantly increased the plant height (93.95 cm, at Harvest stage) as compared to all the treatments. Which was significantly on par with spacing $20 \mathrm{~cm} \times 10$ $\mathrm{cm}+100 \%$ RDN $(92.04 \mathrm{~cm})$ and $20 \mathrm{~cm} \times 10$ $\mathrm{cm}+100 \% \mathrm{~N}$ through vermicompost (92.01 $\mathrm{cm})$.Significantly lower plant height was recorded with $30 \mathrm{~cm} \times 10 \mathrm{~cm}+100 \%$ RDN $(86.97 \mathrm{~cm})$.It could be attributed to the fact that higher plant density would certainly reduce the amount of light availability to the individual plant, especially to lower leaves due to greater shading. As the mutual shading increases at higher plant densities, the plant tends to grow taller. Due to the elongation of nodes of over aged seedlings in the nursery leads to increase in plant height. Similar findings were reported by Rajesh (2011).

\section{Number of tillers/running row meter}

Data pertaining to number of tillers/running row meter is presented in Table 1 revealed that spacing $20 \mathrm{~cm} \times 10 \mathrm{~cm}+50 \% \mathrm{RDN}+$ $50 \% \mathrm{~N}$ through vermicompost significantly increased the number of tillers/running row meter (36.69 at Harvest stage) as compared to all the treatments. Which was significantly on par with treatment of spacing $20 \mathrm{~cm}$ x $10 \mathrm{~cm}$ $+100 \% \mathrm{~N}$ through vermicompost (35.72) and $20 \mathrm{~cm} \times 10 \mathrm{~cm}+100 \%$ RDN (35.19).
Significantly less number of tillers was recorded with $40 \mathrm{~cm} \times 10 \mathrm{~cm}+50 \%$ RDN + $50 \% \mathrm{~N}$ through vermicompost (32.61). Wider crop geometry had given more number of tillers/plant compared to other treatments. The individual plants could have effectively utilized the available resources such as space, foraging area for root system, light utilization etc. and thus enhanced the tiller production at wider spaced treatments. Similarly, increased number of tillers/hills under wider spacing was very well documented by Awan et al., (2007), Kalaraju et al., (2011), Dahal and Khadka (2012).

\section{Plant dry weight (g)}

Dry weight differed significantly due to different spacing and nutrient sources. Among the different treatments significantly higher plant dry weight was recorded with a spacing of $20 \mathrm{~cm} \times 10 \mathrm{~cm}+50 \% \mathrm{RDN}+50 \% \mathrm{~N}$ through vermicompost (12.82 g) as compared to all the treatments (Table 1). Improvement of leaves might have increased the photosynthetic efficiency of finger millet and have induced to produce more plant dry matter production. This was in accordance with the earlier findings of Borale et al., (2002), Kalaraju et al., (2011) and Rajesh (2011).

\section{Yield attributes}

Number of grains/ear head, number of fingers/ear head, fingers length $(\mathrm{cm})$ and test weight (g)

The data in relation to the number of grains/ear head, number of fingers/ear head, fingers length and test weight in Table 2. Itrevealedthatspacing $20 \mathrm{~cm} \times 10 \mathrm{~cm}+50 \% \mathrm{RDN}+$ $50 \% \mathrm{~N}$ through vermicompost was recorded maximum number of grains/ear head (1912.35) which was significantly superior as compared to all the treatments. 
Table.1 Plant height $(\mathrm{cm})$, number of tillers/running row meter and plant dry weight $(\mathrm{g})$ of finger millet as influenced by different spacing and nutrient sources at harvest stage

\begin{tabular}{|c|c|c|c|}
\hline Treatments & $\begin{array}{c}\text { Plant Height } \\
\text { (cm) }\end{array}$ & $\begin{array}{l}\text { Number of Tillers/ } \\
\text { Running Row Meter }\end{array}$ & $\begin{array}{c}\text { Plant Dry Weight } \\
\text { (g) }\end{array}$ \\
\hline $20 \mathrm{~cm} \times 10 \mathrm{~cm}+100 \%$ RDN & 92.04 & 35.19 & 12.41 \\
\hline $20 \mathrm{~cm} \times 10 \mathrm{~cm}+100 \% \mathrm{~N}$ through vermicompost & 92.01 & 35.72 & 12.46 \\
\hline $20 \mathrm{~cm} \times 10 \mathrm{~cm}+50 \% \mathrm{RDN}+50 \% \mathrm{~N}$ through vermicompost & 93.95 & 36.69 & 12.82 \\
\hline $30 \mathrm{~cm} \times 10 \mathrm{~cm}+100 \% \mathrm{RDN}$ & 86.97 & 32.94 & 11.80 \\
\hline $30 \mathrm{~cm} \times 10 \mathrm{~cm}+100 \% \mathrm{~N}$ through vermicompost & 89.31 & 34.14 & 12.12 \\
\hline $30 \mathrm{~cm} \times 10 \mathrm{~cm}+50 \% \mathrm{RDN}+50 \% \mathrm{~N}$ through vermicompost & 87.34 & 33.80 & 12.41 \\
\hline $40 \mathrm{~cm} \times 10 \mathrm{~cm}+100 \% \mathrm{RDN}$ & 89.24 & 33.75 & 12.19 \\
\hline $40 \mathrm{~cm} \times 10 \mathrm{~cm}+100 \% \mathrm{~N}$ through vermicompost & 87.65 & 32.68 & 12.10 \\
\hline $40 \mathrm{~cm} \times 10 \mathrm{~cm}+50 \% \mathrm{RDN}+50 \% \mathrm{~N}$ through vermicompost & 89.97 & 32.61 & 11.71 \\
\hline $\operatorname{SEm}( \pm)$ & 0.6887 & 0.7491 & 0.1924 \\
\hline CD $(p=0.05)$ & 2.0647 & 2.2256 & 0.5717 \\
\hline
\end{tabular}

Table.2 Yield attributes and yield of finger millet as influenced by different spacing and nutrient sources

\begin{tabular}{|c|c|c|c|c|c|c|c|}
\hline Treatments & $\begin{array}{c}\text { Number of } \\
\text { Grains/Ear } \\
\text { Head }\end{array}$ & $\begin{array}{c}\text { Number of } \\
\text { Fingers/Ear } \\
\text { Head }\end{array}$ & $\begin{array}{c}\text { Fingers } \\
\text { Length }(\mathrm{cm})\end{array}$ & $\begin{array}{c}\text { Test } \\
\text { Weight }(\mathrm{g})\end{array}$ & $\begin{array}{c}\text { Grain } \\
\text { Yield (t/ha) }\end{array}$ & $\begin{array}{l}\text { Biological } \\
\text { Yield (t/ha) }\end{array}$ & $\begin{array}{c}\text { Harvest } \\
\text { Index(\%) }\end{array}$ \\
\hline $20 \mathrm{~cm} \times 10 \mathrm{~cm}+100 \%$ RDN & 1898.68 & 6.31 & 8.93 & 3.17 & 2.69 & 7.31 & 36.86 \\
\hline $20 \mathrm{~cm} \times 10 \mathrm{~cm}+100 \% \mathrm{~N}$ through vermicompost & 1799.39 & 5.66 & 8.53 & 3.23 & 2.37 & 6.66 & 35.58 \\
\hline $20 \mathrm{~cm} \times 10 \mathrm{~cm}+50 \% \mathrm{RDN}+50 \% \mathrm{~N}$ through vermicompost & 1912.35 & 6.41 & 9.04 & 3.24 & 2.74 & 7.41 & 37.03 \\
\hline $30 \mathrm{~cm} \times 10 \mathrm{~cm}+100 \%$ RDN & 1763.85 & 5.62 & 8.52 & 2.94 & 2.35 & 6.62 & 35.49 \\
\hline $30 \mathrm{~cm} \times 10 \mathrm{~cm}+100 \% \mathrm{~N}$ through vermicompost & 1797.22 & 5.66 & 8.65 & 3.14 & 2.42 & 6.66 & 36.37 \\
\hline $30 \mathrm{~cm} \times 10 \mathrm{~cm}+50 \% \mathrm{RDN}+50 \% \mathrm{~N}$ through vermicompost & 1866.09 & 6.17 & 8.85 & 3.03 & 2.62 & 7.17 & 36.60 \\
\hline $40 \mathrm{~cm} \times 10 \mathrm{~cm}+100 \%$ RDN & 1730.42 & 5.55 & 8.39 & 3.15 & 2.28 & 6.49 & 35.20 \\
\hline $40 \mathrm{~cm} \times 10 \mathrm{~cm}+100 \% \mathrm{~N}$ through vermicompost & 1667.15 & 5.23 & 8.11 & 3.12 & 2.09 & 6.22 & 33.61 \\
\hline $40 \mathrm{~cm} \times 10 \mathrm{~cm}+50 \% \mathrm{RDN}+50 \% \mathrm{~N}$ through vermicompost & 1695.11 & 5.31 & 8.25 & 2.91 & 2.15 & 6.22 & 34.52 \\
\hline $\operatorname{SEm}( \pm)$ & 17.9277 & 0.2274 & 0.0814 & 0.100 & 0.0462 & 0.2391 & 0.8797 \\
\hline $\mathrm{CD}(\mathrm{p}=\mathbf{0 . 0 5})$ & 53.7474 & 0.6817 & 0.2442 & NS & 0.1385 & 0.7170 & NS \\
\hline
\end{tabular}


Treatment with spacing of $20 \mathrm{~cm} \times 10 \mathrm{~cm}+50 \%$ $\mathrm{RDN}+50 \% \mathrm{~N}$ through vermicompost was also recorded significantly maximum number of fingers/ear head (6.41) which followed by treatment with $20 \mathrm{~cm} \mathrm{x} 10 \mathrm{~cm}+100 \%$ RDN and $20 \mathrm{~cm} \mathrm{x} 10 \mathrm{~cm}+100 \% \mathrm{~N}$ through vermicompost. The treatment of spacing $20 \mathrm{~cm}$ $\mathrm{x} 10 \mathrm{~cm}+50 \% \mathrm{RDN}+50 \% \mathrm{~N}$ through vermicompost was also recorded maximum fingers length $(9.04 \mathrm{~cm})$ which was significantly superior as compared to all the treatments. The consisting of conjunctive application of inorganics and $\mathrm{N}$ through organics was probably due to higher uptake of nutrients that led to better translocation of photosynthates (Aparna et al., 2019). While in case of test weight, treatment with spacing of 20 $\mathrm{cm} \times 10 \mathrm{~cm}+50 \%$ RDN $+50 \% \mathrm{~N}$ through vermicompost was also recorded maximum $(3.24 \mathrm{~g})$ which was followed by treatment with $20 \mathrm{~cm} \times 10 \mathrm{~cm}+100 \% \mathrm{~N}$ through vermicompost and there was no significant difference among treatments. Similar findings were reported by Shinggu and Gani (2012). Plant spacing of 20 $\mathrm{cm} \times 10 \mathrm{~cm}$ with integrated fertilizer management and favorable microclimate to crop for effective utilization of available moisture, nutrient and its early adoption leads to better partitioning of photosynthates to reproductive parts there by recording better growth and yield attributes. Ram et al., (2014) also reported similar findings.

\section{Yield parameter}

\section{Grain yield (t/ha), biological yield (t/ha) and} harvest index $(\%)$

Data pertaining to grain yield, biological yield and harvest index is presented in Table 2 . Treatment with $20 \mathrm{~cm} \times 10 \mathrm{~cm}+50 \%$ RDN + $50 \% \mathrm{~N}$ through vermicompost spacing was recorded maximum Grain yield (2.74 t/ha) and Biological yield $(7.41 \mathrm{t} / \mathrm{ha})$ which was significantly superior as compared to all the treatments. However, in case of Grain yield and biological yield treatment with $30 \mathrm{~cm} \times 10 \mathrm{~cm}+$ $50 \% \mathrm{RDN}+50 \% \mathrm{~N}$ through vermicompost and
$20 \mathrm{~cm} \times 10 \mathrm{~cm}+100 \%$ RDN were statistically on par with treatment of spacing $20 \mathrm{~cm} \times 10 \mathrm{~cm}$ $+50 \% \mathrm{RDN}+50 \% \mathrm{~N}$ through vermicompost. Lower grain yield was recorded under wider spacing because total number of plants per unit area was far lesser than with closer planting. Optimum planting pattern is the prerequisite for proper utilization of growth resources and ultimately to exploit the potential productivity of any crop. This is in agreement with the findings of Rafey and Srivastava (1988).Treatment with $20 \mathrm{~cm} \times 10 \mathrm{~cm}+50 \%$ $\mathrm{RDN}+50 \% \mathrm{~N}$ through vermicompost was also recorded maximum Harvest index $(37.03 \%)$ there was no significant difference among treatments (Table 2).

Grain and Biological yield significantly affected by the closer spacing and judicious use of inorganic with organic manure vermicompost.

In conclusion from the study, however due to the higher plant population at the closer spacing of $20 \mathrm{~cm} \times 10 \mathrm{~cm}$ the number of heads per plant was higher compared to wider spacing. This led to a significantly higher grain yield for the closer spacing as compared to wider spacing. The integrated use of $50 \% \mathrm{RDN}+50 \% \mathrm{~N}$ through vermicompost is the best nutrient management practice that can be adopted to obtain better high yield. Therefore, it is recommended for farmers for receiving higher yield.

\section{Acknowledgement}

I express gratitude to my advisor Dr. Rajesh Singh for constant support and guidance. I am indebted to Prof. (Dr.) Joy Dawson, Dr. Vikram Singh, Dr. Umesha C and Dr. Shikha Singh, Department of Agronomy.

\section{References}

Aparna, K., Bhanu Rakesh, K., Vani, K.P. and Ram Prakash, T. 2019. Growth and yield of Finger Millet as influenced by crop residue composting. Journal of 
Pharmacognosy and Phytochemistry. 8(4): 1108-1111.

Awan, T.H., Ahamed, M., Ali, I., Anwar, M. and Manzoor, Z. 2007. Contribution of tillers with in a rice plant yield and yield components. Journal of Agricultural Research. 45(3): 237- 243.

Bayala, J., Teklehaimanot, Z. and Ouedrogo, S.J. 2002. Millet production under pruned Tree crowns in a parkland system in Burkina Faso. Agrofor. Syst. 54: 203-214.

Borale, J.S., Patil, T.R., Kagane, B.V. and Mahalle, A.M. 2002. Dry matter accumulation and its distribution in various plant parts in finger millet (Eleusine coracana (L). Gaertn.). Journal of Soils Crops. 12(1): 46-48.

Dahal, K.R. and Khadka, R.B. 2012. Performance of Rice with Varied Age of Seedlings and Planting Geometry under System of Rice Intensification (SRI) in Farmer's Field in Western Terai, Nepal. Nepal Journal of Science and Technology. 13(2): 1-6.

Kalaraju, K., Kumar, N.S., Nagaraja, N. and Ningappa, K.B. 2009. Effect of methods of planting on growth and yield of Finger Millet genotypes under organic farming. Research on Crop. 10(1): 20-24.

Korir, A., Kamau, P. and Mushimiyimana, D. 2018. Effect of fertilization and spacing on growth and grain yields of Finger Millet. International Journal of Advanced Research and Publication: 2456-9992.

Rajesh, K. 2011. System of crop intensification in Finger Millet under irrigated condition. M.Sc. (Ag.) Thesis, Tamil Nadu Agricultural University, Coimbatore.

Ram, H.J.P., Singh, J.S., Bohra, J.S., Rajiv, K.S. and Sutaliya, J.M. 2014. Effect of seedlings age and plant spacing on growth, yield, nutrient uptake and economic of rice genotypes under system of rice intensification. Indian Journal of Agronomy. 59(2): 256-260.

Ramamurthy, K., Christoper, Louduraj, A., Alagudurai, S. and Kandaswamy, O.S. 2004. Effect of crop residue management of early season legumes on the succeeding rainfed finger millet. Madras Agril. J. 91(4-6): 180-183.

Rafey, A. and Srivastava, V.C. 1998. Effect of cultivation, seedlings rate and spacing on grain yield of rainfed Finger Millet. Indian Journal of Agronomy. 33(3): 331332.

Resmisa, 2012 (Revalorising Small Millets in Rainfed Regions of South Asia) Supporting Millets in India. Policy Review and Suggestions for Action. p.6 (2012).

Shinggu, C.P. and Gani, M. 2012. Effects of planting methods, sowing dates and spacing on weed and the productivity of Finger Millet in the Northern Guinea Savanna of Nigeria. Global journal of Bio-Science and Biotechnology. 1(2): 160-162.

Upadhayay, P.N., Dixit, A.G., Patel, J.R. and Chayda, J.R. 2001. Response of summer pearl millet (Pennisetum glaucum) to time and method of planting, age of seedlings and phosphorus grown on loamy sand soil of Gujarat. Indian J. Agron. 46(1):126130.

Uphoff, N., Marguerite, T., Devi, J., Behera, D., Verma, A.K. and Pandian, B.J. 2011. National Colloquium on System of Crop Intensification (SCI). In: http://sri.ciifad.cornell.edu/aboutsri/otherc rops/index.html.

\section{How to cite this article:}

Manojgowda, B. S., Rajesh Singh and Wasim Khan. 2021. Effect of Different Spacing and Nutrient Sources on Growth and Yield of Zaid Finger Millet (Eleusine coracana (L.) Gaertn). Int.J.Curr.Microbiol.App.Sci. 10(02): 2907-2912. doi: https://doi.org/10.20546/ijcmas.2021.1002.323 